\title{
A presença e a ausência do costume na moralidade: uma leitura da Antígona de Sóflocles e da República de Platão a partir de Nietzsche
}

\author{
Vânia Dutra de Azeredo*
}

\begin{abstract}
Resumo: Neste artigo, partindo do conceito nietzschiano de eticidade do costume, apresentaremos duas visões de ética na antiguidade grega, quais sejam, a que prescreve o respeito à tradição, em que vige a incondicionalidade da obediência e a que se segue e suplanta a anterior mediante a transposição do valor ao plano imaginário. Surge, então, a incondicionalidade da norma. Palavras-chave: eticidade, costume, tradição, justiça, ação.
\end{abstract}

\footnotetext{
* Universidade Federal do Estado do Rio de Janeiro (UNIRIO), Rio de Janeiro, Rio de Janeiro, Brasil. ORCID https://orcid.org/0000-0002-9519-6194

Correio eletrônico: vd.azeredo@uol.com.br
} 
Azeredo, V. D.

Neste artigo, procuramos mostrar, por um lado, que o conceito de eticidade do costume em Nietzsche expressa uma visão afirmativa da moralidade ao remeter tanto o que se deveria fazer quanto o que jamais poderia ser feito ao costume enquanto poder ordenador. Por outro, dar a conhecer que a crítica de Nietzsche a Platão está relacionada com a Paideia presente e condutora do Livro a República, enquanto propõe uma nova formação para o homem grego. Esse propósito fica manifesto, sobretudo, na expulsão dos poetas e na alteração do sentido da virtude para, por fim, sustentar essa nova formação através do plano imaginário para o qual Platão transfere o valor mediante a introdução da ideia, transformando a visão grega dos deuses, do homem e do agir desse homem.

Comecemos com a eticidade do costume em Nietzsche enquanto mantém sempre presente o sentido de costume referido à eticidade, resgatando o ethos em grego e o mos em latim que a expressão Sittlichkeit der Sitte mantém na língua alemã. Rubens Rodrigues Torres Filho, no volume de Nietzsche da coleção "Os Pensadores", em nota, afirma: "Eticidade ou Moralidade, duas palavras que perderam a referência ao significado original de costume, que têm por base (ethos em grego, mos em latim). O texto alemão, ao dizer Sittlichkeit der Sitte, o evoca muito mais diretamente -, Rubens Rodrigues mostra-nos, "que a língua não perdeu totalmente a memória dessa ligação, tanto que Ética se diz Sittenlehre (doutrina dos costumes) e já Kant reservava a fundamentação da moral para uma "metafísica dos costumes" (Nietzsche, 1978, p. 159). Somente partindo dessa referência ao grego e ao latim pode-se compreender o sentido de Eticidade do costume em Nietzsche, enquanto cumprindo fixar no querer, inclusive como ação desse querer mesmo, alguns "quero" e alguns "não quero". Isso fica evidenciado pela descrição do comportamento humano diante do costume enquanto poder ordenador que determinava o que se deveria fazer e o que jamais poderia ser feito.

Nietzsche situa a Eticidade do costume em uma pré-história da moralidade, fornecendo um plano argumentativo que liga moral, 
cultura e impulsos em uma teia construtora do humano. Descreve o processo de assimilação do costume no homem, o desenvolvimento do hábito de ter hábitos, como uma tarefa que, apesar de fundamental, representa o princípio da formação dele, mas não ele como produto. A proveniência da responsabilidade, em Nietzsche, está diretamente relacionada com a Eticidade do costume, pois a ela coube criar as condições necessárias para o desenvolvimento da responsabilidade. Requerendo, todavia, fazer o homem, primeiramente, confiável e igual entre os iguais; nisso encontra-se a função dessa eticidade em que o homem, enquanto formando a si mesmo, fez-se confiável mediante a ação da comunidade sobre o indivíduo. É o trabalho de moldagem da consciência que se efetiva, ao seu caráter fugidio, definido pelo esquecimento, contrapõe-se uma consistência mediante a introdução da memória. Nela, em nossa leitura, encontramos a possibilidade da passagem da natureza à cultura através da assimilação do costume enquanto incondicionalidade da obediência.

Percebida como a capacidade ou mesmo a condição do humano de obedecer a leis, a eticidade do costume tem por referencial regulador uma superioridade imanente expressa na figura da tradição. Os homens teriam, assim, desde suas origens mais primitivas no sentido da própria constituição do humano pela ação da cultura, sua inscrição social, desenvolvido a atitude de obedecer a leis. $\mathrm{O}$ movimento da cultura é denominado por Nietzsche Eticidade do costume, cuja ação precípua está determinada pelo adestramento, pelo ato de impor a obediência aos próprios costumes enquanto ato fundador da civilidade do homem. Convém observar que nessa dimensão formativa, os próprios costumes, enquanto maneira de agir e de apreciar prescritas para a comunidade, exigiam o cumprimento. Por isso, tudo o que se referia a eles, desde questões de higiene, saúde, relações entre os membros da comunidade estavam sob o jugo da eticidade. Os indivíduos teriam necessariamente de se guiar pelos costumes existentes, de forma que a perspectiva propriamente individual se dirime na observância da tradição, já que ela se apresenta 
como um poder superior, cuja forma de ordenamento está envolta em respeito e medo. Aquele que não obedece ao costume e, portanto, enfrenta o poder da tradição, deveria tornar-se um legislador, um criador de costumes. Tal prática, todavia, constitui-se como perigosa, tendo em vista o poder ordenador que envolve o próprio costume e a conotação imoral daquele que o enfrenta.

O fundamental, nessa perspectiva, não está no que é prescrito, mas na prescrição e na submissão a ela. Pode-se, assim, compreender melhor a importância exacerbada do costume e, inclusive, a impossibilidade da não existência dele. Em alguns casos fica patente que o costume, enquanto modo de agir em determinadas circunstâncias, não importa tanto quanto assimilar a ordenação referida a ele, já que é sobre essa base que se origina a própria civilização. Seguindo essa linha interpretativa, podemos tomar como exemplo da dimensão comum dessa eticidade a extensão punitiva à ação individual, que era sempre compreendida como punição para a comunidade, devido ao relaxamento dos costumes. A preeminência da individualidade como princípio de responsabilidade era tomada necessariamente como não-ética. Em vista disso, a ação individual possuir uma dimensão comum e a falta ser assimilada como algo que se estende aos domínios de toda comunidade.

Entre os contemporâneos de Nietzsche, a impossibilidade de compreender a dimensão dessa moralidade está, para ele, de um lado, no enfraquecimento do costume e, de outro, na perda da dimensão do significado dele que fez com que surgisse uma dificuldade, ou mesmo impossibilidade de se compreender a gênese da moralidade. Quando havia uma relação estreita entre tradição e moralidade, a existência de uma implicava a existência da outra e, de modo inverso, o enfraquecimento da tradição requeria o enfraquecimento consequente da moralidade: "Em coisas onde nenhuma tradição manda não há nenhuma eticidade; e quanto menos a vida é determinada por tradição, menor se torna o círculo da eticidade" (M/A 9, KSA 3.22, 
tradução de RRTF) ${ }^{1}$. A moralidade ou imoralidade estava diretamente relacionada com a tradição pelo respeito ou não a ela. Daí o homem não-ético ser identificado com aquele que "quer depender de si e não de uma tradição".

Na tragédia Antígona, em nossa leitura, vemos a oposição que se estabelece entre eticidade do costume e lei positiva quando as formulações delas são distintas, gerando um conflito entre o costume e a prescrição humana da lei que independa da tradição. ${ }^{2}$ A tragédia Antígona de Sófocles, a nosso ver, remete ao conceito de eticidade do costume proposto por Nietzsche como antecedendo as formulações teóricas gregas que encontramos em Platão e, posteriormente, em Aristóteles acerca da ética. Em vista disso, entendemos haver na Grécia Antiga duas compreensões completamente diferentes alusivas ao agir moral, quais sejam, a eticidade do costume presente no discurso de Antígona na tragédia de Sófocles, que vai ao encontro da exposição nietzschiana acerca da importância da obediência ao costume, do poder da tradição. Momento em que vige uma incondicionalidade da obediência, enquanto instância que permite compreender o agir humano. De outra parte, a formulação que se inicia com Platão e busca fundamentar as ações morais exclusivamente na razão, instaurando a incondicionalidade da norma.

1 Quando for o caso, serão usadas as traduções de Nietzsche para o português feitas por Rubens Rodrigues Torres Filho, Paulo César de Souza e Jacob Guinsburg que serão indicadas, respectivamente, pelas siglas RRTF, PCS e JG. As obras utilizadas constam nas referências.

2 Em Estudos de ética antiga, Marco Zingano propõe encontrar nas peças de Sófocles, especialmente em Antígona, o surgimento de um humanismo em que o humano é apresentado como causa das próprias ações. $\mathrm{O}$ autor situa a ação humana no contraste entre deuses e animais. Ao final do capítulo sobre teatro e ação humana em Sófocles, referindo-se a Antígona, afirma: "Sófocles está em seu esplendor: 'mas única viva entre os mortais, por decisão própria desce ao Hades', ou 'mas, única entre os mortais a viver por decisão própria, desce ao Hades' ou 'mas, por decisão própria, é a única entre os mortais a descer viva ao Hades'. $O$ teatro tem pouca complacência com o espectador. Qualquer que seja a boa leitura, o seguro é que Antígone toma para si as decisões. Nem para ela é claro por que tanta aflição por Polinice, e tão pouca por Eteócles (ou por Hêmon), mas Antigona abandona Tebas por sua própria decisão". Não se trata, em nosso texto, de realizar uma contraposição à leitura do prof. Zingano, mas propor para a mencionada atitude de aflição de Antígona e para o abandona dela de Tebas a incondicionalidade da obediência presente na eticidade do costume consoante nossa leitura de Nietzsche. 
Azeredo, V. D.

Conflitando com o costume, a lei expressa pelo edito de Creonte conduz ao infortúnio crescente dos cidadãos de Tebas, ele especialmente, remetendo à proeminência do costume com relação ao exercício humano de determinar uma lei que dele independa. Podemos observar isso em diversas passagens do texto, entre elas, convém citar a fala de Antígona quando questionada pela desobediência à lei estabelecida por Creonte: "Antígone - Porque não foi Zeus quem a ditou, nem foi a que vive com os deuses subterrâneos - a Justiça - quem aos homens deu tais normas". No final da própria defesa, Antígona resgata o sentido e a importância da tradição presentes nas leis imemoriais ao fazer referência aos juízes da humanidade depois da vida - Hades e Perséfone: “Nem nas tuas ordens reconheço força que a um mortal permita violar aquelas não-escritas e intangíveis leis dos deuses. Estas não são de hoje, ou de ontem: são de sempre; ninguém sabe quando foram promulgadas. A elas não há quem, por temor, me fizesse transgredir, e então prestar contas aos Numes" (Sófocles, 1997, p. 62).

Observe-se, particularmente, a referência da personagem à indeterminação temporal das leis, apontando para uma existência e uma autoria impossíveis de precisar, mas cujo poder ordenador requer o cumprimento de forma inquestionável devido ao costume, que aparece envolto em respeito e medo incomensuráveis. Em vista disso, a alusão ao ter de prestar contas em uma instância maior pela desobediência ao instituído desde sempre na lei dos deuses. Como mortais, não cabe aos humanos questionarem ou desobedecerem ao poder ordenador da tradição que regulamenta o comportamento e o agir moral desde tempos imemoriais, como vemos na fala de Antígona. Acrescente-se a essa fala o que encontramos um pouco antes dito pelo Coro ao enaltecer o portentoso milagre que é o homem devido a todas as potencialidades que o caracterizam como aquele que doma a terra e o oceano, que é senhor da arte e do engenho, que acha remédio para as piores doenças e não consegue fugir apenas da morte. Se no início da fala, temos um relato de admiração referente às potencialidades humanas, no final dela encontramos 
uma resalva condicionante da dignidade humana em termos pátrios que enfatiza o necessário cumprimento das leis e do juramento dos deuses: "Quando respeita as leis e o juramento dos deuses [o humano] é digno da pátria; mas é sem pátria o que por orgulho a conduz ao mal..." (Sófocles, 1997, p. 59).

A ação de Creonte vai de encontro ao que determinam os deuses ao impedir as homenagens funerais de um membro da pátria, ainda que em atitude de confronto a ela, afinal, Polinices ataca Tebas. Todavia, não está em questão o ato de Polinices em vida, mas a violação das leis divinas pelo edito de Creonte ao impedir o sepultamento dele. Essa atitude conflita com os costumes imemoriais da tradição, precipitando o desfecho trágico de Antígona, Hémon (filho de Creonte), Eurídice (esposa de Creonte) e, mais do que todos, do próprio Creonte. Ao entender que o orgulho e a petulância presentes no modo de governar, em desrespeito completo às leis divinas terminaram por provocar a ira dos deuses, Creonte tomba arrependido, mas ainda assim, não altera nada que tenha se desenrolado. A ira dos deuses cai como mão de ferro sobre Tebas, levando ao rompimento de toda e qualquer harmonia existente. Creonte, como todo mortal, não pode querer para trás e carregará no final da tragédia Antígona o fardo pelo levante contra a tradição e contra os costumes vigentes desde há muito em Tebas.

Em termos da tragédia, vemo-na buscando expressar a pura brincadeira dos deuses ao disporem os humanos na hora da cena, como um desenrolar antecipado, por trás da cortina, que lança o herói trágico às suas escolhas para que ele encontre o que é ao desatar os nós do passado na cena do presente. $\mathrm{O}$ feio e o desarmônico fazem parte sempre do jogo artístico. Mediante os infortúnios do herói, tem-se o conhecimento imediato da condição do mundo enquanto processo contínuo de criação e de destruição. O herói morre porque é finito, efêmero, impotente. A fragilidade cede ao tempo e comunga os horrores e as belezas da vida em uníssono. $\mathrm{O}$ espectador trágico percebe-se finito e se percebe como parte do infinito. Assim é o mundo e assim é a tragédia enquanto, como vê Nietzsche, jogo 
Azeredo, V. D.

heraclitiano, movimento do vir-a-ser introduzido pelo filósofo de Éfeso e compartilhado pelo filósofo alemão em sua exposição da tragédia.

Encontramos essas palavras na resposta do Daimon Sileno, companheiro de Dionísio, à indagação do rei Midas sobre o preferível para o homem. Nietzsche relata: "Estirpe miserável e efêmera, filha do acaso e do tormento! Por que me obrigas a dizer-te o que seria para ti mais salutar não ouvir? O melhor de tudo é para ti inatingível: não ter nascido, não ser, nada ser. Depois disso, porém, o melhor para ti é logo morrer" (GT/NT, 3, KSA 1.35, tradução de JG). Sófocles nos diz isso de outro modo por meio do Corifeu apontando, primeiramente, para a pujança da vida de Édipo: "Vede bem, habitantes de Tebas, meus concidadãos! Este é Édipo, decifrador dos enigmas famosos; ele foi um senhor poderoso e por certo o invejastes em seus dias passados de prosperidade invulgar". Na sequência, o Corifeu descreve o completo infortúnio de Édipo, apontando para a fragilidade da condição humana no mundo: "Em que abismos de imensa desdita ele agora caiu! Sendo assim, até o dia fatal de cerrarmos os olhos não devemos dizer que um mortal foi feliz de verdade antes dele cruzar as fronteiras da vida inconstante sem jamais ter provado o sabor de qualquer sofrimento!" (Sófocles, 1998, p. 96)

A nosso ver, a tragédia Antígona de Sófocles remete ao conceito de eticidade do costume proposto por Nietzsche e, nesse sentido, antecede as formulações teóricas gregas que encontramos a partir de Platão acerca da ética. Por isso, Nietzsche diz: "Aqueles moralistas, em contrapartida, que assim como os seguidores das pegadas socráticas inculcam no coração do indivíduo a moral do autodomínio e abstinência como seu proveito mais próprio, como chave pessoal para a felicidade, constituem a exceção - e, se nos parece diferente, é porque fomos educados sob sua influência" (M/A, I $§ 9$, KSA 3.23, tradução de RRTF). Não é exatamente isso que vemos na República de Platão quando o pensador grego expulsa os poetas, transformando o sentido das virtudes gregas e propondo como condição de possibilidade para manter a república ideal uma nova 282 | Cad. Nietzsche, Guarulhos/Porto Seguro, v.42, n.1, p. 275-302, janeiro/abril, 2021. 
A presença e a ausência do costume na moralidade...

Paideia, viabilizadora do estabelecimento de um elo indissolúvel entre estética, ética, política e conhecimento?

Comecemos com a formação do homem grego proposta na obra A República a fim de compreender a importância desse ponto para Platão, fazendo-o mostrar como os poetas introduzem uma educação que deve ser banida de uma República Ideal administrada pelo filósofo em que cada elemento encontra o lugar conforme a natureza. Ao apresentarem as qualidades antropomórficas dos deuses, isto é, como tendo ira, desejo, maldade, cobiça e, ainda, metamorfoseandose em algo menor os poetas prestariam um desserviço à unidade e à coesão da $A$ República, pois fariam com que os modelos dela fossem vulneráveis ao invés de inquebrantáveis. De outra parte, a mesma vulnerabilidade expressa no herói pelos poetas, exigindo ser presenteado pelos feitos ao invés de fazê-lo conforme o que lhe cabe pela sua natureza, poderia comprometer a formação dos guardiões. Acrescente-se a isso, as considerações que ele tece sobre a música, cuja harmonia "deve imitar convenientemente a voz e as inflexões de um homem valente na guerra ..." (Platão, 1987, p. 128, Livro III, 399b).

Ao retomarmos essas alegações, podemos entender a importância da instrução e da educação para formar o cidadão da República, bem como para mantê-la unida, pois é através da educação que se tornarão homens comedidos e capazes de perceber os preceitos que devem seguir. Por isso, encontramos, primeiramente, uma alusão à base dela: "...a república, uma vez que esteja bem lançada, irá alargando como um círculo". E, posteriormente, a referência à importância da educação nela: "uma educação e instrução honestas que se conservam tornam a natureza boa, e, por sua vez, naturezas honestas que tenham recebido uma educação assim, tornam-se ainda melhores que seus antecessores, sob qualquer ponto de vista..." (Platão, 1987, 168, Livro III, 421e). É por isso que Platão considera que aqueles que estão encarregados da cidade devem apegar-se a esse sistema de educação evitando qualquer inovação que afete as regras estabelecidas para a ginástica e a música. Ora, isso nos leva a compreender a consideração negativa 
de Platão acerca do gosto pela novidade enquanto decorrência da pobreza ou da riqueza. Para o filósofo grego, “... nunca se abalam os gêneros musicais sem se abalar as mais altas leis da cidade" (Platão, 1987, p. 169) como afirma Dâmon: “A inobservância das leis, para o autor de a República, pode passar sem que se perceba através da música. Nas palavras de Adimanto, lemos:

Nada mais faz, na realidade, do que introduzir-se aos poucos, deslizando mansamente pelo meio dos costumes e usanças. Daí deriva, já maior, para as convenções sociais; das convenções passa às leis e às constituições com toda insolência, Ó Sócrates, até que, por último, subverte todas as coisas na ordem pública e na particular" (Platão, 1987, p. 170, Livro III, 424 e).

Por isso, a formação das crianças deve se dar a partir de jogos em conformidade com a lei e de uma música que as conduza a boa ordem para, posteriormente, descobrirem as leis que os antecessores deixaram se perder, quais sejam: - silêncio dos mais novos perante os mais velhos; - dar o lugar e levantar-se para os mais velhos; - cuidados para com os pais; -cuidados para com o corte de cabelo, o traje, o calçado e toda compostura do corpo; - outras como essas. Na ótica platônica, a educação tem um papel importante como impulso que, ao ser dado, determinará o que o educado irá seguir a fim de atingir um ponto perfeito e sólido. Por isso, não precisam estabelecer leis para os homens de bem, já que eles as descobrirão por si mesmos, enquanto os demais poderão passar a vida inteira a fazer leis e a corrigilas para buscar uma perfeição que, segundo esse entendimento, foi comprometida pela ausência de um impulso inicial, de uma educação que, de fato, prime pela honestidade. Daí a educação ser fundamental para a formação da cidade em termos de coesão e honestidade de todas as partes que a compõe e para alterar a compreensão das virtudes.

Considerando que se a cidade foi bem fundada, então ela é necessariamente e totalmente boa e, uma vez sendo boa, que é forçoso que nela estejam presentes as virtudes básicas, Platão pode seguir ao encontro na cidade da sabedoria, da coragem, da temperança e 284 | Cad. Nietzsche, Guarulhos/Porto Seguro, v.42, n.1, p. 275-302, janeiro/abril, 2021. 
da justiça nela presentes. Observemos que nesse ponto, o filósofo faz decorrer a presença das virtudes do fato de a cidade ser boa porque foi bem administrada e fundada, quer dizer, enuncia um paralelismo entre ser bom e ser virtuoso no plano da cidade. É por ela ser boa que necessariamente é sábia, é corajosa, é temperante e é justa. A partir disso seguirá a ordem de exposição das virtudes enumeradas mencionando que o que restar corresponderá ao que procuravam desde o início, isto é, a justiça que é apenas anunciada como tema no Livro I.

Convém ressaltar que se enuncia também na obra do filósofo grego uma relação da vida feliz com a cidade, pois para que a questão inicial acerca da justiça seja respondida é preciso antes compreender a presença das virtudes na cidade, lembrando ainda a proposição platônica da semelhança entre o maior e o menor, bem como da importância da felicidade do todo e da relação dela com a parte: “... estamos a modelar, segundo cremos, a cidade feliz, não tomando à parte um pequeno número, para os elevar a esse estado, mas a cidade inteira". (Platão, 1987, p. 162, 420a).

Em A República, 428a, Platão propõe uma forma de proceder para encontrar a justiça na cidade. Partindo da determinação das virtudes sabedoria, coragem e temperança encontrarão a justiça como aquela que resta depois de as outras terem sido postas a claro. Nesse ponto, pareceria à primeira vista que a justiça seria menos importante, já que o autor faz uma alusão a ela como a que restaria, todavia, trata-se do contrário, conforme o texto mostrará na sequência. Além disso, convém lembrar que a cidade é bem fundada em função da ordem e da unidade que a caracterizam, fazendo-a, necessariamente boa e, por isso, portadora das virtudes.

Através do atributo ponderação presente na cidade e já atestado pela ordem e unidade que a caracterizam, a sabedoria é localizada mediante uma inquirição do que seria ponderar em termos da cidade: "A cidade que analisamos parece-me ser realmente sábia, uma vez que é ponderada, não é?" (Platão, 1987, p. 177, 428c). Posteriormente, o autor mostra que a ponderação é uma espécie de ciência, pois pela 
Azeredo, V. D.

ignorância não se poderia deliberar bem. Uma vez admitido o sentido da afirmação, restaria saber dentre as muitas ciências, qual a que torna a cidade sábia. Nesse caso, o pensador grego estabelece uma diferença entre as ciências importantes para o fazer de cada artífice e a ciência que trata não de pormenores, mas da totalidade: "Existe alguma ciência, na cidade que há pouco fundamos, em alguns de seus cidadãos, pela qual delibera, não sobre qualquer pormenor que nela se encontre, mas sobre a sua totalidade, sobre a melhor maneira de se comportar consigo mesma e perante as outras cidades?" (Platão, 1987, p. 177, 428d).

A vigilância é apresentada, então, como a ciência que permite responder pelo todo e por cada parte da cidade, encontrando-se, justamente, naqueles chefes que seriam guardiões perfeitos: "Essa ciência é a vigilância - respondeu ele -, e encontra-se naqueles chefes que agora mesmo classificávamos de guardiões perfeitos" (Platão, 1987, p. 178, 428d). Estabelecendo que o número de guardiões perfeitos é menor do que o de artífices ou de qualquer outro, Platão enuncia que quando esses guardiões perfeitos, dominadores da ciência da totalidade, presidirem e chefiarem a cidade, ela será portadora da virtude da sabedoria, já que a sabedoria na cidade se manifesta em a cidade ter sido fundada conforme a natureza. Nesse caso, cada classe ocupa o lugar conforme também a natureza de cada uma, lembrando que, como afirma Platão, "...é graças à mais diminuta classe e sector, e à ciência que encerra, ao que ocupa a presidência e a chefia, que uma ciência fundada de acordo com a natureza é toda ela sábia" (Platão, 1987, p. 178, 428e).

As considerações sobre a coragem na cidade são determinadas pelo setor que luta e combate por ela, mas desde que mantenha a posição que deve ter apesar de todas as adversidades que vierem a se apresentar em qualquer circunstância: "a cidade é corajosa numa das partes, pelo facto de aí armazenar energia tal que preservará através de todas as vicissitudes a sua opinião sobre as coisas a temer, que são tais e quais as que o legislador proclamar na educação"

286 | Cad. Nietzsche, Guarulhos/Porto Seguro, v.42, n.1, p. 275-302, janeiro/abril, 2021. 
(Platão, 1987, p. 179, 429a). Percebemos com essa afirmação e as seguintes, que a coragem não consiste em lutar destemidamente, mas em uma espécie de salvação que faz com que a pessoa se conserve no propósito para o qual foi designada, apesar dos desgostos, dos prazeres, dos desejos e dos temores. Por isso, o termo salvação tem o sentido de um salvar-se de si e de tudo aquilo que estimule uma ação contrária à natureza, contrária às leis e à educação em que foram introduzidos, nesse caso, diferindo de salvar a cidade, de salvar alguém ou mesmo salvar a si. A coragem na cidade é “...uma força desta ordem, salvação em todas as circunstâncias de opinião recta e legítima, relativamente às coisas temíveis e às que não o são, que eu chamo coragem..." (Platão, 1987, p. 180, 430b).

Observe-se que se introduz uma negação dos ditames do corpo, pois o prazer é apresentado como mais temível que qualquer soda em uma comparação com o processo de tintura, ajuntando-se, na sequência, o desgosto, o temor e o desejo. Trata-se de rejeitar de modo absoluto o ditame determinado pelos impulsos naturais, que do ponto de vista da cidade não são conforme a natureza da classe ${ }^{3}$.

Parecendo, em certos aspectos com a coragem, a temperança remete à ordenação e à contenção de prazeres e de desejos manifesta, notadamente, na expressão "ser senhor de si” (Platão, 1987, p. 182, 430e). Para que não se cofunda que o mesmo homem pode ser escravo e senhor de si, Platão estabelece haver uma diferença entre as partes que comandam esse homem, no caso, as da alma. Quando alguém

3 Convém assinalar que a filosofia de Nietzsche se contrapõe àquela dos desprezadores do corpo, como Platão e a tradição filosófica - entendida de Descartes a Hegel. Em "Das cátedras e da virtude", o autor procura desvalorizar as virtudes enquanto entendidas tanto no sentido de disposição para a prática do bem, quanto de boa qualidade moral. A imagem do sábio com seus quarenta pensamentos faz Zaratustra rir, porque entende a virtude de uma outra forma. Daí ele conceder ao sábio conhecimentos no que concerne ao sono e não à ação. Em "Dos ultramundanos", é a introdução do conceito de corpo que permite a Nietzsche distinguir as condições orgânicas nas interpretações, desde a interpretação das condições. Em "Dos desprezadores do corpo", o filósofo parte da seção anterior e faz a distinção entre pequena e grande razão, mostrando que o corpo, enquanto grande razão, é quem interpreta, mas que aqueles que o desprezam, como os espíritos de suportação, não podem ser ponte para o além-do-homem.

Cad. Nietzsche, Guarulhos/Porto Seguro, v.42, n.1, p. 275-302, janeiro/abril, 2021. | 287 
Azeredo, V. D.

é dominado pela parte pior, é chamado de libertino e escravo de si, ao contrário, quando a melhor parte domina, ele é senhor de si e, por isso, temperante. Ser senhor de si implica em ter "sentimentos simples e moderados, dirigidos pelo raciocínio conjugado com o entendimento e a recta opinião" (Platão, 1987, p. 183, 430e). A virtude da temperança enquanto se assemelha à harmonia, deve estar, para Platão, por toda a cidade, levando-o a defini-la a partir da concordância entre partes melhores e piores sobre a quem compete a regência seja no indivíduo seja na cidade: "a temperança é esta concórdia, harmonia, entre os naturalmente piores e os naturalmente melhores, sobre a questão de saber quem deve comandar, quer na cidade quer num indivíduo" (Platão, 1987, p. 184, 432b).

A introdução do tema da justiça a partir da definição das outras virtudes na cidade guarda uma singularidade, pois Platão faz uma alusão ao fato de eles sempre estarem a falar dela de algum modo: "sem nos apercebermos que era da justiça que estávamos a tratar" (Platão, 1987, p. 185, 432c); lembrando Adimanto do princípio estabelecido desde o início: cada um deve ocupar na cidade a função conforme a natureza de modo a fazer o que lhe é mais adequado, Platão principia por dizer que a justiça seria executar a própria tarefa sem se meter na do outro. Isso seria, de certa forma, a justiça, na medida em que dava às demais virtudes a força para se constituírem como virtudes. A definição de justiça e injustiça propostas vai ao encontro dessa afirmação à medida que prescreve como justo "a posse do que pertence a cada um e a execução do que lhe compete" (Platão, 1987, p. 187, 434d), vinculando a justiça ao ocupar na cidade a função conforme a natureza. De outra parte, a injustiça proviria da confusão entre as classes, quando uma delas subtraísse-se à função própria e quisesse exercer outra ou se apossasse dos instrumentos da outra. Assim, a fim de manter a cidade em ordem e unida cada um deve ocupar na cidade a função conforme a natureza, tendo para isso, conforme a citação anterior "a posse do que pertence a cada um e a execução do que lhe compete" como justiça.

288 | Cad. Nietzsche, Guarulhos/Porto Seguro, v.42, n.1, p. 275-302, janeiro/abril, 2021. 
A presença e a ausência do costume na moralidade...

Embora não mencione, no método de comparação entre o indivíduo e a cidade está presente a seguinte proposição: o menor assemelhasse ao maior ou aquilo que encontramos no maior encontraremos no menor. A defesa dessa proposição está presente em todo livro e mesmo no que concerne à justiça, caso não haja adequação, deve-se retornar à cidade (maior) para depois verificar novamente o menor, indicando, com isso, que não é a regra de semelhança entre maior e menor que levou ao equívoco, mas a análise feita previamente. Daí Platão afirmar: “o homem justo, no que respeita à noção de justiça, nada diferirá da cidade justa, mas será semelhante a ela" (Platão, 1987, p. 190, 435b). No argumento platônico, se o estabelecimento da justiça na cidade se deu a partir da presença nela de três naturezas, a justiça no indivíduo também terá de tê-las.

No livro IV da República, Platão nos encaminha para o sentido presente na tripartição da cidade e da alma, mas para entendermos a relação entre elas devemos ter presente a afirmação do livro II: “... observando a semelhança com o maior na forma do menor." (Platão, 1987, p. 72, 369a). A responda de Sócrates a Adimanto acerca da felicidade dos guardiões que não pode ser determinada por eles, à parte, mas pelo todo, quer dizer, a cidade, indicada já no início do livro IV nos mostra a relação existente entre o cidadão e a Cidade em termos de uma copertença especial, que faz com que a felicidade da parte, isto é, do cidadão, dependa da realização da felicidade no todo, na Cidade. Com isso, Platão não quer dizer que uns têm mais direito de serem felizes do que outros, mas mostrar que o tema da felicidade está diretamente ligado à figura do cidadão como parte integrante da Cidade e que a possibilidade de realização dela se encontra na harmonia da Cidade que justamente fará com que cada parte seja feliz somente na medida em que o todo for feliz: “... estamos a modelar, segundo cremos, a cidade feliz, não tomando à parte um pequeno número, para os elevar a esse estado, mas a cidade inteira". (420a)

Entre 436e e 44lc, Platão propõe-se a determinar se a alma possui ou não três partes. Nesse ponto, a maior dificuldade não está em 
Azeredo, V. D.

perceber a presença da irascibilidade, do gosto pelo saber ou do amor pela riqueza nos cidadãos, como nos casos citados em exemplos dos da Trácia, da Grécia ou do Egito respectivamente, mas de determinar se provêm da alma como um todo ou de uma parte dela. Isso se torna complicado pela rejeição desde o início do livro da multiplicidade e de tudo que pode ser e pode não ser nesse tema manifesto na declaração: "É evidente que o mesmo sujeito não pode, ao mesmo tempo, realizar e sofrer efeitos contrários nas mesmas das suas partes e relativamente à mesma coisa" (Platão, 1987, p.191, 436e e 441c).

Ora, a alegação de Platão já permite antever a resposta no que concerne à alma, isto é, terá de ter três partes a fim de não realizar e sofrer efeitos contrários nas mesmas das suas partes. Por isso, o recurso ao exemplo do pião mostra que ele não está a se mover em ambas as partes, mas em relação ou ao eixo ou à circunferência. Para Platão a proposição: “jamais o mesmo sujeito poderá sofrer, ser ou realizar efeitos contrários na mesma das suas partes e relativamente à mesma coisa" (Platão, 1987, p. 193, 436e e 441c) deverá nortear a compreensão acerca do ser e da verdade. Nesse plano, não pode jamais ser colocada em questão, pois requereria que algo pudesse ser e não ser: No livro VII, o filósofo estabelecerá a dessemelhança entre o mundo sensível e o suprassensível, que nos permitirá compreender as diferenças entre o ser e a mudança.

No plano das atividades da alma, o filósofo grego mostrará que não podemos considerar que aquilo que deseja e aquilo que constrange ou freia o desejo sejam o mesmo, já que uma coisa é ter sede e outra é conter a busca pela satisfação da sede. Quanto ao desejo, é o desejo de algo a partir do qual se originou e, nesse caso, dependente da coisa que se deseja, mesmo que se deseje o que é bom, pois não faz sentido, em tomando o exemplo acima, desejar uma água ruim. Mas, o autor faz questão de frisar que o desejo de $\mathrm{x}$ é sempre relativo a $\mathrm{x}$ e não a mais ou menos $\mathrm{x}$, não o inteiro ou a metade de $\mathrm{x}$, querendo assinalar a distinção entre o desejar relativo ao desejado e aquilo que freia o desejo, impedindo a realização ou 290 | Cad. Nietzsche, Guarulhos/Porto Seguro, v.42, n.1, p. 275-302, janeiro/abril, 2021. 
satisfação dele. Não poderiam ser as mesmas partes da alma sem que produzissem ao mesmo tempo resultados contrários: “....são dois elementos, distintos um do outro, chamando aquele pelo qual ela raciocina, o elemento racional da alma, e aquele pelo qual ama, tem fome e sede e esvoaça em volta de outros desejos, o elemento irracional e da concupiscência" (Platão, 1987, p. 198, 436e e 441c). Assim, Platão diferencia o elemento que raciocina daquele graças ao qual se deseja. Acrescenta ainda a cólera como um terceiro elemento a frear a concupiscência na busca da satisfação do desejo, pois que se mostra contrária a ele antes da sua realização: "quando as paixões forçam o homem contra a sua razão, ele se censura a si mesmo, se irrita com aquilo que, dentro de si, o força, e que, como se houvesse dois contendores em luta, a cólera se torna aliada da razão" (Platão, 1987, p. 199, 436e e 441c).

A alma, assim como a cidade, tem três partes: a racional, a irascível e a concupiscente e da mesma forma que aquela deverá ser sábia, corajosa, temperante e justa conforme o que foi apresentado na cidade. À razão caberá governar por ser sábia e por velar pela alma inteira. À cólera caberá guiar-se pela razão, sendo sua aliada. Será corajosa, sempre que preservar as instruções da razão sobre o que é ou não temível. Por fim, será temperante quando houver harmonia entre as partes, de modo que o governante (razão) governa os outros dois (cólera e concupiscência) sem que haja revolta de nenhuma parte, mas ordem e harmonia. Caberá à educação e à instrução educar para que a maior parte da alma, concupiscente, obedeça à razão. Em cada parte, realizando aquilo que lhe cabe por natureza, a alma, como a cidade, será justa:

$\mathrm{Na}$ verdade, a justiça era qualquer coisa neste gênero, ao que parece, excepto que não diz respeito à actividade externa do homem, mas à interna, aquilo que é verdadeiramente ele e o que lhe pertence, sem consentir que qualquer uma das partes da alma se dedique a tarefas alheias nem que interfiram umas nas outras, mas depois de ter posto a sua casa em ordem no verdadeiro sentido, de ter autodomínio, de se organizar, de se tornar amigo 
Azeredo, V. D.

de si mesmo, de ter reunido harmoniosamente três elementos diferentes, exatamente como se fossem três termos numa proporção musical, o mais baixo, o mais alto e o intermediário, e outros quaisquer que acaso existam de permeio, e de os ligar todos, tornando-os, de muitos que eram, numa perfeita unidade, temperante e harmoniosa, só então se ocupe (se é que se ocupa) ou da aquisição de riquezas, ou dos cuidados com o corpo, ou de política ou de contratos particulares, entendendo em todos estes casos e chamando justa e bela à ação que mantenha e aperfeiçoe estes hábitos, e apelidando de sabedoria a ciência que preside a esta ação; ao passo que denominará de injusta a ação que os dissolve a cada passo, e ignorância a opinião que a ela preside (Platão, 1987, p. 204-205, 441c-44la).

Ora, se a justiça na alma correspondia à harmonia entre elas a partir da obediência das partes (cólera e concupiscência) à razão, a injustiça apresenta-se como sendo o contrário, quer dizer, uma ingerência ou sublevação de uma parte contra o todo a fim de dominar, fazendo com que a parte que cabe obedecer mande e tente fazer obedecer àquela que compete mandar. Nesse caso, ao invés de ordem e de harmonia, haveria desordem e desarmonia. As perturbações e os desvios resultam em injustiça que se manifesta na libertinagem, na covardia, na ignorância e em toda espécie de maldade segundo Platão. Em subvertendo a ordem que deveria viger, elas não diferem da doença e da saúde no que concerne ao corpo. Assim como as coisas sãs produzem saúde no corpo e as doentias a doença, produzir a saúde na alma consistiria em dispor os elementos em ordem conforme a natureza, enquanto o inverso geraria a doença na alma: "produzir a saúde consiste em dispor, de acordo com a natureza, os elementos da alma, para dominarem ou serem dominados uns pelos outros; a doença, em, contra a natureza, governar ou ser governado um por outro" (Platão, 1987, p.206, 444a-444e). Para Platão, com a injustiça e a justiça processa-se o mesmo: “...produzir a justiça consiste em dispor, de acordo com a natureza, os elementos da alma, para dominarem ou serem dominados uns pelos outros; a injustiça, em, contra a natureza, governar ou ser governado um por outro" (Platão, 1987, p.207, 444a-444e). Por isso, 
Platão concluirá dizendo que a virtude será "uma espécie de saúde, beleza e bem-estar, enquanto o vício será uma enfermidade, fealdade e debilidade" (Platão, 1987, p.207, 444a-444e), considerando que os bons costumes levam à posse da virtude e os vergonhosos ao do vício.

Em termos de virtudes e de vícios, Platão traz um problema, considerado por ele importante ao questionar a relação entre a prática da justiça ou da injustiça com a visibilidade ou não dela, indagando: "se é proveitoso exercitar a justiça, praticar belas ações e ser justo, quer passe despercebido ou não o nosso procedimento, ou cometer a injustiça e ser injusto, ainda que se não tenha de pagar a pena nem nos tornemos melhores com o castigo" (Platão, 1987, p. 207, 444a-444e), todavia o autor não termina de respondê-la; ainda assim, através dela menciona à problemática constante no livro II (360c) diante do anel que fazia o portador ficar invisível, mostrando, naquela altura do texto, que toda pessoa se não fosse vista, seria injusta ao invés de justa, conforme relato de Glauco. Além disso, alude também à questão da velhice através do argumento de Adimanto sobre a falta de sentido da questão socrática, já que estabelece um paralelo entre o decair da constituição física e a ruína do princípio pelo qual se deveria viver, lembrando-nos do elogia feito no início do livro I acerca da velhice de Céfalo e do controle dos déspotas desenfreados em tal idade por ele, que correspondem justamente às paixões ou à concupiscência, parte que, por natureza, deve obedecer à razão.

Quando as paixões cessam de nos repuxar e nos largam, acontece exatamente o que Sófocles disse: somos libertos de uma hoste de déspotas furiosos. Mas, quer quanto a estes sentimentos, quer quanto aos relativos aos parentes, há uma só e única causa: não a velhice, ó Sócrates, mas o caráter das pessoas. Se elas forem sensatas e bem dispostas, também a velhice é moderadamente penosa; caso contrário, ó Sócrates, quer a velhice, quer a juventude, serão pesadas a quem assim não for." (Platão, 1987, p. 5, 329d).

Ora, considerando que Adimanto e ele chegaram até tal ponto, Platão julga ser pertinente mostrar que há uma única forma de virtude, 
Azeredo, V. D.

enquanto infinitas de vício, em que pese quatro delas estarem entre as que são importantes para se recordar. Estabelecendo novamente o paralelo entre a cidade e a alma, determina haver correspondência entre o número de constituições e o de almas. No capítulo, discorrerá somente sobre a constituição que corresponde à virtude e que, não por acaso, coincide com a República una proposta por Platão, ainda que seja governada por um homem, chamando-se monarquia ou por mais homens, nesse caso, aristocracia: "Contudo, isso considero-o eu como uma só forma de constituição, porquanto, quer haja vários, quer um só, não abalarão as leis importantes da cidade, desde que tenham a educação e instrução que expusemos" (Platão, 1987, p.208, 445a).

Há de se observar que, na República de Platão, encontramos uma contraposição direta à compreensão de justiça proposta pelos sofistas. A exposição de Trasímaco bem o mostra quando defende ser justiça a conveniência do mais forte. ${ }^{4}$ Ao remeter as leis promulgadas aos poderes constituídos, enquanto detentores de uma robustez, ele reforça o mesmo entendimento. Tais poderes, no discurso de Trasímaco, detêm a força e, por isso, salvaguardam a conveniência dos mais fortes, dos mais poderosos na determinação da justiça e da lei. Encontramos a corroboração da leitura sofista da justiça no Livro II da República, em que a personagem Glauco se dispondo a resgatar a argumentação de Trasímaco discorre sobre o que é a justiça, a origem dela, a relação inversa entre praticá-la e querer praticá-la, continuando até determinar ser melhor ser injusto do que justo. A proveniência da justiça, na exposição de Glauco, está determinada pela instituição das leis e das convenções. Somente o cumprimento ou desobediência a elas permitem estabelecer o justo e o injusto, lembrando que a obediência corresponde à submissão ao poder de outro, assemelhando-se à concepção de justiça como expressão de quem tem força, poder, domínio sobre aquele que a eles e submetem.

4 Cf. Platão, 1987, p. 23 “Afirmo que a justiça não é outra coisa que a conveniência do mais forte".

294 | Cad. Nietzsche, Guarulhos/Porto Seguro, v.42, n.1, p. 275-302, janeiro/abril, 2021. 
O modo como Nietzsche compreende a justiça, em nossa ótica, coaduna-se com as asserções de Trasímaco na República. O autor de Ecce homo situa a justiça no processo formativo que, assim como a eticidade do costume, situa-se na pré-história da humanidade, enquanto antecede as formulações teóricas de Sócrates e Platão, resgatando a necessidade de fazer no homem uma memória da vontade, fazê-lo capaz de prometer, o que, para o filósofo alemão, encontra meio nas relações contratuais que equiparavam dano e dor. Na base da introdução do castigo está a cólera pelo dano sofrido; ainda assim é a ideia de equivalência, paridade, medida que sustenta a relação dano/dor. São as relações contratuais que permitem equipará-los:

De onde tirou seu poder essa ideia imemorial, profundamente enraizada, hoje, talvez, inextirpável, de uma equivalência entre dano e dor? Como eu já disse, da relação contratual entre credor e devedor, relação tão antiga quanto a existência de "pessoas jurídicas", e que leva, por sua vez, às formas fundamentais da compra, da venda, da troca, do tráfico (GM/GM, II, 4, KSA 5.298, tradução de PCS)

Na visão nietzschiana, não se castigava por responsabilidade diante do ato e sim por raiva devido ao dano e, inclusive, se introduzia a dor como um elemento que lhe era equivalente. Desse modo, o castigo não poderia ter uma conotação moral, mas, diferentemente, buscava-se através dele uma reparação ou restituição do dano. Em vista disso, a sua remessa direta à esfera contratual. Esse tipo de relação está presente principalmente nas promessas, pois se fazia um contrato em que o devedor empenhava algo de seu ao credor como garantia do cumprimento da palavra. A confiança no cumprimento da promessa, para Nietzsche, requeria o empenho de algo que o promitente possuísse, de modo que este dispunha de seu corpo, sua mulher, sua vida, ou mesmo a tranquilidade pós-morte (cita o caso dos egípcios) como elementos de troca, objetos de garantia que respaldavam o empenho da palavra pela possibilidade de restituição do dano, caso a promessa não fosse cumprida. Isso se efetivava de tal modo que o 
Azeredo, V. D.

credor podia, de fato, dispor do devedor: "O credor podia naturalmente infligir ao corpo do devedor todo tipo de humilhações e torturas, como, por exemplo, cortar um pedaço que parecesse corresponder à grandeza da dívida" (GM/GM, II, 5, KSA 5.299, tradução de PCS).

A ideia de compensação tem por base um deleite interno, uma satisfação promovida por poder dispor de outrem. Nietzsche atribui ao credor a possibilidade, mediante a punição, de participar de um "direito dos senhores", que seria justamente a intensificação de potência, experimentada através da subjugação do devedor. Por isso, ele equipara um bem - terra, dinheiro etc. - à descarga da própria potência mediante a dor infligida ao devedor. A satisfação aparece como recompensa pelo dano sofrido e será tanto maior quanto mais baixo for o nível do devedor em termos estamentais, já que lhe possibilita o gozo através do distanciamento e superioridade que o elevam. Na base da equiparação entre dano e dor, na ideia mesma da compensação, está presente, como imperante, o prazer na crueldade. A obtenção do direito de ser cruel diretamente - o credor executa a pena - ou mesmo indiretamente - a execução fica a cargo de uma autoridade - lhe dá prazer e isso, nesse momento, justifica a equiparação dano-dor: "A compensação representa, assim, um convite e um direito à crueldade" (GM/GM, II, 5, KSA 5.300, tradução de PCS).

É no âmbito das relações materiais entre comprador e vendedor que surgem, segundo o filósofo de Sils Maria, o direito e a justiça, pois foi a partir da medida, do peso, enfim, do ato de estimar que o homem chegou ao estabelecimento de direitos e deveres. A justiça recebe, assim, em Nietzsche, outro estatuto, já que a relação entre dor e esquecimento, em vista do estabelecimento de uma memória da vontade, remete ao próprio papel da justiça. $\mathrm{O}$ dano representa justamente o não cumprimento da promessa e, com isso, o esquecimento diante da palavra empenhada. Em vista disso, a dor é tanto equiparada ao esquecimento, quanto imposta como meio determinante de sua suspensão temporária, cabendo-lhe fixar na memória uns "quero" e uns "não quero". O castigo aparece como

296 | Cad. Nietzsche, Guarulhos/Porto Seguro, v.42, n.1, p. 275-302, janeiro/abril, 2021. 
meio necessário para fazer no homem uma memória: “castigo como um fazer-memória” (GM/GM, II, 13, KSA 5.318, tradução de RRTF) - um dos sentidos possíveis do castigo. Se a necessidade de fazer no homem uma memória remonta a sua pré-história, então a equivalência entre dano e dor, enquanto modo de suspensão do esquecimento, também remonta e, justamente aí, deve-se situar a justiça, que torna o devedor responsável por uma dívida. Uma tal determinação aponta para a "origem"5 do sentimento de culpa e de obrigação pessoal.

O sentimento de culpa tem sua gênese na relação entre comprador e vendedor, credor e devedor: "aqui entrou pela primeira vez pessoa contra pessoa, aqui se mediu pela primeira vez pessoa a pessoa." (GM/GM, II, 8, KSA 5.306, tradução de RRTF). Essas relações, tidas por Nietzsche como as mais antigas encontradas entre os homens, apontam para o homem como aquele que valora, mede pessoa a pessoa, isto é, estabelece equivalência entre uma pessoa e outra. A troca e a valoração, na sua perspectiva, são tão fundamentais para o início do pensar humano que acabam por definilo e nisso encontra-se, inclusive, o sentimento de superioridade do homem sobre os demais animais, nessa sua capacidade de medir e valorar: "Talvez exprima ainda nossa palavra 'Mensch' (manas) algo, precisamente, desse sentimento de si: o homem se designou como o ser que mede valores, que valora e mede, como o 'animal' estimador em si" (GM/GM, II, 8, KSA 5.306, tradução de RRTF). Para Nietzsche, as relações entre comprador e vendedor, credor e devedor, antecedem qualquer organização social e só posteriormente passam a ser transpostas para as comunidades, uma vez que tais relações se estabelecem primeiramente entre as pessoas. Mais tarde,

5Em Nietzsche, a questão da origem nunca se apresenta como busca de um primeiro princípio explicativo, visto ser a origem um elemento secundário diante da diversidade de sentidos que um dado pode ter. Por isso, o recurso à origem constitui-se como retomada de sentidos expressos na história, buscando a verificação da mais remota postulação. Em Aurora, 44, Nietzsche afirma que: "Com a compreensão da origem aumenta a falta de significação da origem, enquanto o mais próximo, o em-torno-de-nós e o em-nós começa pouco a pouco a mostrar cores e belezas e enigmas e riquezas de significação com os quais a humanidade antiga nem sequer sonhar" (M/A 44, KSA 3.52, tradução de RRTF).

Cad. Nietzsche, Guarulhos/Porto Seguro, v.42, n.1, p. 275-302, janeiro/abril, 2021. | 297 
Azeredo, V. D.

elas atingem um tal refinamento que se passa a perceber em tudo um valor, fazendo com que cada coisa existente tenha um preço, um equivalente.

... Logo se chegou, com grande generalização, a "cada coisa tem seu preço, tudo pode ser pago" - o mais antigo e mais ingênuo cânon moral da justiça, o início de toda "bondade", de toda "equidade" sobre a terra. Justiça, nesse primeiro grau, é a boa vontade, entre os que têm potência mais ou menos igual, de se acomodarem uns aos outros, de, por meio de um igualamento, voltarem a se "entender" - e, em referência aos que têm menos potência, coagi-los, abaixo de si, a um igualamento. (GM/GM, II, 8, KSA 5.306, tradução de RRTF)

A noção de justiça procede da possibilidade de o homem, medindo pessoa a pessoa, diferenciar os que têm mais ou menos potência, e estabelecer direitos e deveres entre os iguais. Em vista disso, os iguais ajustam-se entre si e subjugam aqueles que têm menos potência. Estabelece-se, por conseguinte, uma diferença entre o grupo de mais potentes e um de menos potentes, sendo que a boa vontade se estende aos de potência igual, o que remete àquela noção de igualdade entre os iguais já mencionada. A extensão à comunidade se dá à medida que essas relações permeiam as demais entre os membros da comunidade. Vale observar que, nesse caso, os iguais são os próprios membros da comunidade, que acordam em agir conforme suas prescrições, não obstante a necessária cobrança ao indivíduo que quebra o acordo e a sua subsequente proscrição. A partir disso, ele perde os benefícios dos costumes que o protegiam e contra os quais ele se rebela, daí a necessidade do castigo ${ }^{6}$ como cobrança do credor, no caso, a comunidade, sobre o devedor, infrator:

\footnotetext{
6 Nietzsche enfatiza que, nesse momento, devido ao grau atingido de aquisição de costumes, o castigo aparece como uma espécie de cópia, de reprodução de um comportamento usual diante do inimigo. Em Para a genealogia da moral, II, § 9, afirma: “ $\mathrm{O}$ 'castigo', nesse grau de aquisição de costumes, é simplesmente a imagem, a mímica do procedimento normal que se tem contra o inimigo odiado, tornado indefeso, derrubado, que não perdeu somente todo direito e proteção, mas também toda clemência;". (GM/GM, II, 9, KSA 5.307, tradução de RRTF)
}

298 | Cad. Nietzsche, Guarulhos/Porto Seguro, v.42, n.1, p. 275-302, janeiro/abril, 2021. 
O infrator é um devedor, que não somente não pagou pelas vantagens e adiantamentos que lhe foram demonstrados, mas até mesmo atenta contra seu credor; por isso, de agora em diante, não somente perde, como é justo, todos esses bens e vantagens - mas é agora recordado do quanto valem esses bens. (GM/GM, II, 9, KSA 5.307, tradução de RRTF)

Para o filósofo alemão, em todos os tempos, o direito sempre esteve ligado aos fortes e poderosos como impositores da lei e, a partir disso, do que é justo e injusto. Não existe justo e injusto em si, mas tão somente em relação a uma lei estabelecida: "Em consequência, não há 'justiça' e 'injustiça' a não ser a partir da instituição da lei” (GM/GM, II, 11, KSA 5.312, tradução de PCS).

A justiça, nessa acepção, está necessariamente ligada à afirmação, e, por conseguinte, à ação e nunca ao ressentimento: “do ponto de vista histórico, o direito aparece precisamente no mundo como uma luta contra os sentimentos reativos, a guerra combatida contra eles pelas potências ativas e agressivas, que utilizam uma parte de sua força para conter o transbordamento do pathos reativo e para constrangê-los a ceder" (GM/GM, II, 11, KSA 5.311, tradução de PCS). A justiça visa à intensificação e afirmação da vida, nada obstante os estados de direito constituírem-se como "estados de exceção", haja vista a restrição expansiva da vontade de potência em busca de mais potência. Através da imposição da lei restringe-se a manifestação dela, pois, segundo a compreensão de Nietzsche, "a vida procede essencialmente, isto é, nas suas funções elementares, por infração, violação, exploração, destruição, e ela não pode ser pensada sem isso" (GM/GM, II, 11, KSA 5.312, tradução de PCS). Referenda-se, desse modo, a impossibilidade do justo ou injusto em si e corrobora-se a sua relação direta com a instituição da lei, conforme compreensão dos sofistas na República de Platão.

A justiça que começou pelo "tudo pode ser pago, tudo deve ser pago" acabou por fechar os olhos e por deixar correr o insolvente - ela acabou, como toda boa coisa da terra, por destruir-se a si mesma. Esta autodestruição 
Azeredo, V. D.

da justiça, sabe-se que belo nome ela se dá: é a graça; ela se torna, isso vem por si, a prerrogativa do mais forte, ou, ainda melhor, seu para-além do direito" (GM/GM, II, 10, KSA 5.309, tradução de PCS).

Recusando derivar a justiça de uma causa final, Nietzsche a concebe enquanto produto do trabalho árduo da eticidade do costume devido à determinada relação de forças. Daí o filósofo afirmar: "Mas todos os fins, todas as utilidades, são apenas sinais de que uma vontade de potência se tornou senhora de algo menos poderoso e, a partir de si, imprimiu-lhe o sentido de uma função." (GM/GM, II, 12, KSA 5.314, tradução de RRTF). Em vista disso, entendermos haver na Grécia Antiga duas compreensões completamente diferentes alusivas ao agir moral, quais sejam, a eticidade do costume que contamos exemplificar através da tragédia Antígona, especialmente nas falas da personagem que lhe dá título, em que vemos o encontro com a exposição nietzschiana acerca da importância e da obediência ao costume; da vigência, em nossa ótica, de uma incondicionalidade da obediência, enquanto instância para compreender o agir humano. E, de outra parte, a moral socrático-platônica, notadamente, a formulação que se inicia com Platão ao buscar fundamentar as ações morais na razão desde a tripartição da alma e das ideias ou formas.

A defesa de que o conhecimento do conhecimento recordado pode ser obtido unicamente pelo pensamento por meio do questionamento dialético, em Platão, está relacionada com a teoria das formas ou ideias enquanto conhecimento referente ao ser, ao que é eterno e imutável. O papel ético e estético referente a elas corrobora a crítica nietzschiana e nossa argumentação, pois no caso da Justiça, Virtude e Bem aparecem como garantia de objetividade em questões éticas. As formas estéticas assegurariam essa objetividade nesse plano. Desse modo, tanto a Justiça quanto o Belo, por exemplo, têm uma objetividade não podendo ser consideradas expressão de crença ou convenção de pessoas ou grupos de pessoas enterrando por completo a eticidade do costume. Consoante a Nietzsche, a

300 | Cad. Nietzsche, Guarulhos/Porto Seguro, v.42, n.1, p. 275-302, janeiro/abril, 2021. 
oposição, mundo verdade, mundo aparente, tem em Platão a "forma mais antiga da Ideia” e, nessa oposição, o autor situa o mais longo erro da humanidade, enquanto no seu ultrapassamento, o Meiodia, justamente o ponto alto dessa humanidade que coincide com a superação das dualidades proposta pela filosofia de Nietzsche.

\title{
The presence and the absence of custom in morality: a reading of Sophocles' Antigone and the Plato's Republic through Nietzsche
}

\begin{abstract}
In this article, starting from the Nietzschean concept of custom ethics, we will present two visions of ethics in the Greek antiquity, which are, the one that prescribes the respect of tradition, in which rules the unconditionality of obedience and the one that follows and supersedes the anterior through the transposition of value to the imaginary plane. Arises then, the unconditionality of norm.
\end{abstract}

Keywords: Customs Ethics, tradition, justice, action.

\section{Referências}

NIETZSCHE. Oeuvres philosophiques complètes. Edição organizada por Giorgio Colli e Mazzino Montinari. 18 volumes, Paris: Gallimard, 1971/1997. 18 vol.

Sämtliche Werke - Kritische Studienausgabe, edição organizada por Giorgio Colli e Mazzino Montinari. 15 volumes. Berlim: Walter de Gruyter \& Co./DTV, 1980.

. Obras Incompletas, coleção "Os Pensadores", tradução de Rubens Rodrigues Torres Filho, São Paulo, Abril Cultural, 1978. 
Azeredo, V. D.

. Para além de bem e mal, Trad. Paulo César Souza, São Paulo: Companhia das Letras, 1992.

. Genealogia da Moral. Trad. Paulo César Souza, São Paulo: Brasiliense, 1987.

. O nascimento da tragédia, Trad. J. Guinsburg, São Paulo: Companhia das Letras, 1999.

2004 .

. Aurora. Trad. Paulo César Souza, São Paulo: Companhia das Letras,

PLATÃO. A República. Tradução Maria Helena da Rocha Pereira. 4 ed. Lisboa: Fundação Calouste Gulbenkian, 1987.

SÓFOCLES. "Antígone”. Tradução Guilherme de Almeida, in ALMEIDA, G.; VIEIRA, T. Três tragédias gregas. São Paulo: Perspectiva, 1997.

SÓFOCLES. "Édipo rei”. Tradução Mario da Gama Kury, in: SÓFOCLES. Trilogia Tebana. 8 ed. Rio de Janeiro: Zahar, 1998.

ZINGANO, M. Estudos de ética antiga. 2 ed. São Paulo: Paulos; Discurso Editorial, 2009.

Enviado: 24/09/2020

Aceito: 15/11/2020

302 | Cad. Nietzsche, Guarulhos/Porto Seguro, v.42, n.1, p. 275-302, janeiro/abril, 2021. 